\title{
A semântica da forma
}

\section{Franklin de Mattos}

egundo escreveu certa vez Peter Szondi (1929-1971), três vias se abriram às poéticas dos gêneros literários, depois que Hegel transformou em categorias históricas a lírica, a épica e a dramática. Para alguns, como Benedetto Croce, os três gêneros haviam perdido, com a essência sistemática, sua razão de ser; para outros, como Emil Steiger (de quem aliás Szondi foi aluno), deviam continuar a ser tratados de maneira atemporal, como modos de ser do próprio homem.

Restava por fim "perseverar” no terreno da história, não se limitando à poesia, mas incluindo outros gêneros, como fizeram "A Teoria do Romance", de Georg Lukács, "A Origem do Drama Barroco Alemão", de Walter Benjamin, e "A Filosofia da Nova Música", de Theodor Adorno. Desenvolveu-se assim uma espécie de "semântica da forma", em que a dialética entre a forma e o conteúdo aparece como dialética entre o enunciado da forma e o do conteúdo, e em que uma proposição pode entrar em contradição com a outra. Este é o caso da antinomia entre forma dramática e conteúdo épico nas obras de Ibsen, Tchékhov, Strindberg, Maeterlinck e Hauptmann, que para Szondi engendra o teatro moderno. ${ }^{1}$

Pode ocorrer ainda que um enunciado oculte o outro ou só remeta a ele de modo oblíquo, como se deu no drama burguês em sua origem, conforme mostra o livro Teoria do drama burguês - Século XVIII, destinado às preleções do autor e publicado alguns anos após sua morte. ${ }^{2}$

É como se Peter Szondi estivesse empenhado em responder a uma espécie de truísmo: por que é burguês o drama burguês? Mas a pergunta só é descabida se aplicada ao drama pós1770, de Mercier, de Schiller ou do Stürm und Drang, em que aparece às claras o conflito de classe entre burguesia e nobreza. Não é ao se tratar de três peças anteriores, que aliás serviram de modelos para todo o gênero: "O Mercador de Londres", de Lillo, "O Pai de Família", de Diderot, e "Miss Sara Sampson", de Lessing. Na primeira, embora o protagonista

Franklin de Mattos é professor de estética e filosofia da arte no Departamento de Filosofia da USP e autor, entre outros livros, de O filósofo e o comediante - Ensaios sobre literatura e filosofia na ilustração (Editora UFMG, 2001) e A cadeia secreta - Diderot e o romance filosófico (Cosac \& Naify, 2004).

1 Szondi, Peter. Teoria do drama moderno (1880-1950). São Paulo, Cosac \& Naify, 2001.

2 Szondi, Peter. Teoria do drama burguês. Trad. de Luiz Sérgio Repa. São Paulo, Cosac \& Naify, 2005. 
seja um aprendiz de comerciante, seu destino aparentemente não tem nenhum conteúdo de classe e, nas demais, os heróis nem sequer pertencem à burguesia, mas à baixa aristocracia.

Portanto, o próprio Georg Lukács e Arnold Hauser não têm inteira razão ao afirmar que o drama foi o primeiro a desenvolver uma oposição consciente de classe, do mesmo modo que Lothar Pikulik não tem nenhuma ao pretender que o ideal de humanidade do gênero é estranho a qualquer classe. ${ }^{3}$ Assim, a finalidade da pergunta acima é refinar os métodos da "sociologia da literatura", tornando claras "as mediações [...] pelas quais as obras e suas teorias foram condicionadas historicamente".

A primeira mediação a discutir é teórica: o drama nasce ao contestar a "cláusula dos estados", interpretação de Aristóteles existente pelos menos desde a "Ars Grammatica", de Diomedes (século IV d.C.), e para a qual os personagens da tragédia deviam ser forçosamente de condição principesca.

$\mathrm{Na}$ "Dedicatória” do "Mercador" (1731), George Lillo afirma que a tragédia é o mais excelente e o mais útil dos gêneros poéticos; que sua utilidade consiste em excitar as paixóes e corrigir aquelas que são criminosas, por natureza ou excesso; e que, a fim de aperfeiçoar-lhe a excelência, deve-se ampliar sua utilidade, permitindo que se estenda à humanidade em geral, sujeita aos mesmos infortúnios dos grandes senhores.

No "Prólogo", o argumento é outro, mas a questão é a mesma: embora por tradição "a musa da tragédia" mostre aos reis, com majestade e pompa, "a estranha vicissitude das coisas cá embaixo", o próprio teatro inglês já a viu "em trajes mais modestos" e, em vez de despertar terror, "encher de lágrimas" os olhos do espectador. É também o caso da presente peça, que trata da "desgraça privada" de um aprendiz de mercador e da mulher que o extravia, cuja cul- pa e desespero "recomendam a virtude dos bons e dos justos".

Tanto na "Dedicatória" quanto no "Prólogo", ao defender um gênero dramático assentado na abolição da distância entre os personagens e o público, Lillo não argumenta no plano, por assim dizer, "sociológico", mas no poético. Não diz nada acerca do monopólio da nobreza e dos direitos da burguesia sobre a fábula trágica, detém-se no efeito da tragédia. Sustenta que, para ter um efeito amplo, esta não pode se restringir a reis, príncipes e generais (tudo se passa, diz Szondi, como se a tragédia precisasse do burguês e não o burguês da tragédia...). Ora, se assim for, a representação da ação trágica muda completamente de sentido. Antigamente, a tragédia cantava a ruína dos povos, para que os reis aprendessem com seus exemplos como são instáveis as coisas que constituem o mundo. No presente, lamenta a dor de um homem simples, em cujo destino todos se reconhecem: já não fala da natureza do mundo, mas da conduta de um indivíduo, que não é propriamente um exemplo, mas um contra-exemplo.

A outra mediação decorre da própria peça. Em duas cenas passageiras, "O Mercador" (1731) faz o elogio dos comerciantes de Londres, dos quais um ato patriótico salvara a Inglaterra, e do comerciante em geral, cuja "vocação" estaria assentada na razão e cuja obra é uma espécie de "esclarecimento prático": a superação dos obstáculos naturais e convencionais - "Sejam os mares que separam os continentes, sejam a religião e os costumes que separam os povos". Mas não é isso que torna a peça um drama burguês e sim a dupla moral que decorre de sua fábula e que já aparece em seu título igualmente duplo: "The London Merchant" ou "The History of George Barnwell”. Segundo Szondi, esse título "Formula desde o início o contraste entre a norma, que qua norma permanece anônima,

3 Respectivamente em Sobre a sociologia do drama moderno (1914), História social da arte e da literatura (1953) e Drama burguês e sentimentalidade (1966). 
uma característica do gênero, e a exceção lamentável que é de natureza individual e responde pelo nome de George Barnwell”.

A norma é Trorowgood, na firma do qual é aprendiz o próprio Barnwell. Trorowgood encarna as virtudes do comerciante puritano a serem descritas no clássico de Max Weber, "A Ética Protestante e o Espírito do Capitalismo". Essa ética, baseada antes de mais nada no princípio do dever profissional, distinge o novo capitalista tanto dos que desprezam os bens terrenos quanto daqueles que os perseguem a qualquer preço. Weber chamou-a de "ascese intramundana". Seu momento religioso, contido na idéia de "vocação", de "chamamento", é fundamental: conforme as palavras de Weber, "O Deus do calvinismo exigia dos seus não 'boas obras' isoladas, mas a santidade de uma obra desenvolvida em sistema”. Violar essa ética representa portanto uma espécie de esquecimento do dever: é o que faz Barnwell, o aprendiz arruinado, que se deixa arrebatar pela fatal Milwood e por isso torna-se ladrão, assassino e acaba na forca.

De Lillo a Diderot parece haver um retrocesso, por duas razões: 1) os protagonistas de Diderot são da pequena nobreza e suas peças se passam longe do espaço público, na intimidade da família; 2) ao invocar, em sua poética, os modelos de seus personagens, Diderot escolhe, dentre outros, uma rainha e retoma um argumento de ninguém mais que Corneille. Mas não há retrocesso algum, apenas um refinamento das mediações. Para Diderot, quem nos comove na "Ifigênia", de Racine, quando Clitemnestra se aflige com o sacrifício da filha, não é a rainha de Argos ou a esposa do chefe supremo da armada grega, mas apenas a mãe, que exprime seus sentimentos "em toda sua verdade". Portanto, Diderot só menciona a rainha para em seguida despojá-la de sua realeza. Outro exemplo confirma a regra: a camponesa que lamenta a morte do marido, morto pelo próprio irmão dela, não será menos patética que a mulher de alta condição, caso ela diga o que "todo o mundo" diria naquele momento.
Embora preserve a tragédia clássica, Diderot volta a atacar a cláusula dos estados, mas em vez de a tomar como "obstáculo", usa outra estratégia: considera-a "irrelevante". Os reis nos comovem não porque são reis, mas porque são homens, como os espectadores, humanidade que, aliás, também aparece numa simples camponesa. A mediação que está por trás desses exemplos é o conceito de natureza humana, verdadeiro objeto do teatro, que justifica tanto a comédia heróica, cujos personagens cômicos são de alta condição, quanto o drama, cujos protagonistas são pessoas privadas.

Através dos modelos da mãe e da viúva, vislumbram-se dois dramas de família que permitem passar para as mediações das próprias peças de Diderot. O que há de burguês em "O Pai de Família", em que pesem seus personagens nobres e seu argumento, é a nova maneira de tratar o tema da "ausência do filho". Na tragédia clássica, o filho ausente é objeto de inquietação porque o pai-monarca o suspeita de juntar-se a seus inimigos e cobiçar o trono; na comédia jocosa, ele é vítima de um pai prepotente e tirânico, aliás - não por acaso -, burguês. $\mathrm{Na}$ comédia séria de Diderot, sua ausência se torna sinal do dilaceramento da família, que o desenlace acaba por devolver à harmonia perdida. Diderot celebra a família como o lugar da verdade e da virtude, no qual a natureza humana aparece tal como é na realidade, a saber, boa, por oposição ao espaço público, onde triunfam o vício e a perversidade.

Essa família, burguesa, patriarcal e reduzida, surgida por volta do século XVII, distingue-se das famílias aristocrática e camponesa devido à nítida distinção entre o "público" e o "privado". As diferenças entre Lillo e Diderot são portanto enormes. Enquanto "O Mercador de Londres" ensina a probidade, a sinceridade, a pontualidade, a lealdade e a diligência, virtudes do protestantismo ascético que fazem parte dos domínios público e privado, e cujo exercício conduz o burguês à riqueza e ao poder; na França de "O Pai de Família”, a virtude é algo privado, sinal de impotência da 
burguesia, que se consola ao fugir da perversidade do espaço público.

Essa é uma das razões que levam Diderot a preferir o gênero intermediário aos demais. Mas seus escritos são complexos e deve-se insistir não apenas na continuidade, mas igualmente nas tensões entre a teoria e a prática de seu teatro. Com efeito, o filósofo também justifica o drama em nome de uma concepção que faz da arte algo de "enorme, bárbaro e selvagem", produzida por um Gênio que não se submete a regra alguma, só à natureza e, por isso, é capaz de "transtornar" o espectador. Paradoxalmente, sustenta Szondi, Diderot se distancia não só da tragédia clássica, mas igualmente da doméstica, que pretende fundamentar e desse modo antecipa o Sturm und Drang.

Essa interpretação do culto da virtude no teatro de Diderot talvez se confirme pelas reflexôes de Lessing sobre a catarse.

Enquanto Lillo e Diderot, cada um a seu modo, sustentam que a compaixão tem em vista exortar o espectador a uma conduta virtuosa, para Lessing - dramaturgo e teórico de enorme importância para o drama, e que traduziu para o alemão a poética e as comédias de Diderot a própria finalidade da tragédia é provocar "lágrimas de compaixão", fazendo-nos sentir nossa própria "condição humana". Ao traduzir o termo "phobos", usado por Aristóteles em sua "Poética, por "temor", e não por "terror", Lessing pretende que, na tragédia, o espectador se aflige menos com o outro do que consigo mesmo (ou, se quisermos, consigo mesmo mediante o outro). Em consequiência, "O postulado da semelhança entre o personagem dramático e o espectador é inserido na definição do efeito trágico", tornando-se inerente à tragédia.

Não é por acaso, assim, que Lessing dedicou boa parte de seu tempo a pensar que condições devem ser preenchidas para se obter esse temor. Numa carta de 1756, o autor da "Dramaturgia de Hamburgo" distingue três graus na compaixão: a comoção, as lágrimas, o aperto no coração. Sinto comoção quando tenho uma idéia obscura tanto da infelicidade quanto das qualidades de um objeto: comove-me, por exemplo, a figura de todo mendigo. Se essa idéia se torna mais clara, se conheço melhor primeiro as boas qualidades, em seguida as desgraças do mendigo ou vice-versa, a comoção aumenta, mas não chega às lágrimas. Só o fará, caso eu tome conhecimento de ambas ao mesmo tempo, se o mendigo me contar que perdeu o emprego, que está enfermo e na miséria, com mulher e filhos, porque recusou corromper-se a mando de seu superior. Segundo Lessing, a "verdadeira arte de provocar as lágrimas" baseia-se num perfeito equilíbrio entre "desgraça e mérito".

Podemos verificá-lo se mexermos sucessivamente nesses dois pratos, aumentando o peso de cada qual. Primeiro no da perfeição. Se o mendigo diz: "Mas deixe estar, tão logo melhore, voltarei a trabalhar, pouco importa em quê, pois qualquer modo de ganhar o pão é digno, do mais nobre ao mais humilde", minhas lágrimas cessam, sufocadas pela admiração. Nesse caso, deixamos o domínio da tragédia, pois segundo Lessing - ao contrário de Corneille e do estoicismo romano - a admiração rompe o equilíbrio entre infelicidade e ato magnânimo, sendo incompatível com o gênero.

Em seguida, Lessing experimenta com o outro prato. $\mathrm{O}$ mendigo é repelido em toda parte, sua miséria aumenta a cada dia e, no extremo do desespero, ele dá cabo da mulher, dos filhos e da própria vida. Segundo o que tudo indica, estamos aqui no terceiro grau da compaixão: o aperto no coração. Nesse caso, a dor sufoca minhas lágrimas, mas não a compaixão, como fizera a admiração, embora também se esteja fora do terreno da tragédia, pois agora dáse peso excessivo ao prato da desgraça.

Que implicações políticas e sociais pode ter uma estética que define as lágrimas como efeito próprio da tragédia, excluindo as hipóteses da admiração e do aperto de coração? A pergunta não é descabida, se pensarmos nos futuros desdobramentos do drama: 1) em "O Preceptor", de Lenz, o protagonista acaba cometendo uma autocastração análoga ao gesto desesperado do mendigo de Lessing, como se a 
agressão da burguesia impotente se voltasse contra si mesma e não contra aqueles que lhe negam o poder; 2) a hipótese da admiração prefigura o idealismo alemão, que apoiou a Revolução Francesa e forneceu os meios de negar, pela Idéia, as condiçõos sociais, em vez de as aceitar em lágrimas (é o caso da tragédia de Schiller).

A conclusão de Szondi é clara: enquanto o espectador burguês quiser praticar a compaixão no teatro, a tragédia terá como herói-modelo a vítima impotente do arbitrário absolutista, cuja ação se limita à família. Ou ainda: enquanto não se insurgir contra o absolutismo e não reivindicar o poder, a burguesia viverá segundo sua sensibilidade e, impotente, chorará no teatro a miséria que lhe é imposta, nas palavras de Diderot, pelos "perversos" que a cercam. Assim, a insurreição do burguês marcará para o drama o fim da sensibilidade e da compaixão como objetos da tragédia. Com o Sturm und Drang e Lenz o drama se voltará principalmente para a sociedade em que um funcionário, a fim de permanecer honesto, precipita-se na miséria.

Notoriamente e apesar de seu caráter inacabado, o livro de Peter Szondi inscreve-se na melhor tradição da reflexão crítica marxista. Porém, seu epílogo, que examina "Do Teatro ou Novo Ensaio sobre a Arte Dramática”, de Louis-
Sébastien Mercier, tem algo datado que não deixa de provocar no leitor um mal-estar incontornável. Para Szondi, aquilo que distingue o drama cívico de Mercier do drama burguês de Diderot e de Lessing é que o primeiro não se limita a mostrar a "vie domestique" em seu isolamento, representando justamente os momentos em que as forças dominantes no Estado e na sociedade nela irrompem. Nenhuma objeção. O incômodo começa quando ele afirma que, embora rendendo homenagem à "estética do efeito" e à poética dos gêneros de Diderot, Mercier daria "um passo decisivo" além do autor de "O Pai de Família": enquanto Diderot ainda fala do Homem, Mercier já trata do "cidadão", formulando, "pela primeira vez", aquilo "que nos anos vinte do século passado se chamaria um teatro político, nos anos cinqüenta um teatro engajado e hoje um teatro crítico". O livro de Szondi começa valorizando as formas teatrais que, por assim dizer, sublimam a política, sem deixar de falar dela. Curiosamente, a metáfora do "passo adiante" o leva a tomar a direção oposta e considerar como uma espécie de modelo justamente o teatro que tende a abolir as mediações. Entre outras razões, talvez por isso o autor nunca tenha se animado a publicar a "Teoria do Drama Burguês", em que pese sua sofisticada elaboração. 